\title{
The Effects of lodine Deficiency on Thyroid Hormone Deiodination
}

\author{
Maria-Jesus Obregon, Francisco Escobar del Rey, and Gabriella Morreale de Escobar
}

Iodine deficiency induces multiple intrathyroidal autoregulatory changes leading to an increased triiodothyronine $\left(T_{3}\right)$ production and secretion, at the expense of thyroxine $\left(T_{4}\right)$. It is characterized by low serum $T_{4}$, normal or slightly elevated $\mathrm{T}_{3}$, and as a consequence of the latter, normal thyrotropin (TSH). Tissues are also hypothyroxinemic, but their $\mathrm{T}_{3}$ concentrations are mostly normal and ensure clinical euthyroidism, except for those that depend to a high degree on local generation from $\mathrm{T}_{4}$ by extrathyroidal mechanisms involving the iodothyronine deiodinases isoenzymes. Thus, unless iodine deficiency is so severe and chronic that intrathyroidal and extrathyroidal mechanisms are no longer sufficient to maintain a normal $\mathrm{T}_{3}$ in most tissues, individuals are clinically and biochemically euthyroid, but some tissues may be selectively hypothyroid (i.e., the brain). In adults both the intrathyroidal and the extrathyroidal mechanisms reacting to the iodine deficiency are fully operative even when the latter is mild. They contribute jointly to the maintenance of elevated or nor$\mathrm{mal}_{3}$ in those tissues deriving most of it from the plasma, until iodine deficiency becomes very severe. Those depending to a large extent from local generation from $\mathrm{T}_{4}$, mostly by an interplay between type 2 iodothyronine deiodinase (D2) and type 3 (D3), may already be $\mathrm{T}_{3}$-deficient (and hypothyroid) with mild iodine deficiency. Therefore, thyroid status of the iodine-deficient individual not only depends on the degree of iodine shortage, but is mostly tissue-specific, and is difficult to define for the individual as a whole: elevated, normal, and low concentrations of $\mathrm{T}_{3}$ are found simultaneously in different tissues of the same animal, even with severe deficiencies. Most effects of iodine deficiency are reversed in the adults with an adequate iodine prophylaxis, but the absence of $\mathrm{T}_{4}$ during early fetal life leads to irreversible brain damage (neurologic cretinism). Thyroid hormones of maternal origin are available to the embryo early in development and continue contributing to fetal thyroid hormone status, even after onset of fetal thyroid secretion. In the case of congenital hypothyroidism and normal maternal $\mathrm{T}_{4}$, the transfer of the latter, together with increased D2 activity, protects the fetal brain from $\mathrm{T}_{3}$ deficiency, even when it may be insufficient to maintain euthyroidism in other fetal tissues. Practically all of the $T_{3}$ found in the fetal brain is derived locally from $T_{4}$, and not from circulating $T_{3}$. In the case of severe iodine deficiency, both the embryo and the mother are $\mathrm{T}_{4}$-deficient; therefore, the fetal brain is exposed to $\mathrm{T}_{3}$-deficiency, both before and after onset of fetal thyroid function. This leads to irreversible alterations and damage to the central nervous system (i.e. abnormal corticogenesis). Moreover, because intrathyroidal autoregulatory mechanisms are not yet operative in the fetus, both $T_{4}$ and $T_{3}$ continue to be very low until birth, and the fetus is not only hypothyroxinemic, similar to its mother, but also clinically and biochemically hypothyroid.

\section{Introduction}

I ODINE IS AN ESSENTIAL micronutrient required for the synthesis of thyroid hormones. Iodine is very abundant in the sea but is very scarce in many areas of the world. Despite its scarcity and the fluctuations in its availability, throughout evolution vertebrates have not been able to free themselves from the need for iodine-containing hormones. Instead, they have developed specialized mechanisms to maintain a sta- ble secretion of thyroid hormones when confronted with situations of iodine deprivation. During prolonged periods of severe iodine deficiency these mechanisms could become insufficient to meet the thyroid hormone requirements. Most of our understanding on the adaptation to iodine deficiency has been obtained using animal models (mainly rat, sheep, and marmoset, a primate) maintained on low iodine diets (LID) of variable degrees of deficiency (1-6). These models help us to understand the situation and health problems of

Instituto de Investigaciones Biomedicas Alberto Sols, Consejo Superior de Investigaciones Cientificas (CSIC) and Universidad Autonoma de Madrid (UAM), Madrid, Spain. 
the people living in areas of endemic goiter, caused by iodine deficiency.

One of the main problems when summarizing our present knowledge about iodine deficiency is the diversity of animal models used, the different strains, variable length of the treatments, and the different composition of the diets that have been used. A brief comparison of the great experimental variables between different reported studies (1,7-28) highlights the many factors that influence the corresponding results and conclusions. The tracer amounts of other components of the diet (i.e., selenium [Se], vitamins) could also influence the response of the deiodinases in different organs (29-31) and therefore the metabolism of thyroid hormones. All these variables should be taken into account.

Despite all these differences in the severity of the iodine deficiency and in the presence of possible confounding factors, both in animals and in epidemiologic studies, it has become increasingly evident that thyroid autoregulation plays a prominent role in situation of inadequate iodine intake, and also that the extrathyroidal mechanisms may contribute to the maintenance of normal intracellular triiodothyronine $\left(\mathrm{T}_{3}\right)$ concentrations - and ensuing biologic actions-as long as possible.

We review the changes caused by iodine deficiency in thyroid hormone metabolism, especially through deiodinating pathways, in adults and during fetal and postnatal life, as well as the effects on early brain development, the irreversible neurologic manifestations, and the relevance of these findings for humans. As a major part of the studies related to iodine deficiency in different experimental animals have been performed before deiodinase activities and expression could be assessed directly, they are not discussed extensively here, and the reader is referred to previous reviews for the rat, sheep, and marmoset $(1,3,32)$.

Most of the alterations in thyroid hormone metabolism described above could be reversed by the administration of iodide in the diet using the adequate amounts of iodine, except for the irreversible insults to the fetal brain presumably occurring at early stages of development. So it is evident that the study of the events occurring during gestation in the fetus and specifically in the developing brain deserve closer attention.

\section{lodine Deficiency in Adults}

\section{Thyroid autoregulation}

Both in experimental animals and in humans the initial and immediate response to a decreased availability of iodine is the triggering of very efficient autoregulatory mechanisms, such as the increase in vascularity and in iodine uptake. Despite this, if the decreased availability of circulating iodide persists, there is a progressive increase in the ratios of iodothyrosines (monoiodotyrosine [MIT] to diiodotyrosine [DIT]) and iodothyronines $\left(\mathrm{T}_{3}\right.$ to thyroxine $\left.\mathrm{T}_{4}\right)$, leading to the preferential synthesis of $T_{3}$ in the thyroid $(11,1420,33)$. There is a decrease in the proportion of mature fully iodinated (19 S) thyroglobulin (Tg) and an increase in poorly iodinated forms that leak more easily into the bloodstream (20). It appears that the intrathyroidal deiodination of $\mathrm{T}_{4}$ into $\mathrm{T}_{3}$ further increases the preferential secretion of $\mathrm{T}_{3}$. Thus, increased serum $T_{3} / T_{4}$ ratios and $T g$ are typical markers of these autoregulatory mechanisms. An unexpected finding was that all these changes are independent of thyrotropin (TSH; 34-35), occurring when hypophysectomized animals are fed a low iodine diet, whether or not they are substituted with TSH. The increase in thyroid weight and volume, that are part of the autoregulatory changes, do not necessarily mean that circulating TSH is, or has been, increased. The rapid autoregulatory response to a decreased iodine intake has been confirmed in humans (36).

As a result of the autoregulatory mechanisms only circulating $\mathrm{T}_{4}$ decreases, but serum $\mathrm{T}_{3}$ does not, and might even increase (37-38), thus preventing the increase in serum TSH and the clinical signs of hypothyroidism. Elevated TSH is rarely found in goitrous individuals from areas with iodine deficiency alone $(38,39)$.

\section{Hypothyroidism versus hypothyroxinemia}

Iodine deficiency in humans has been frequently and inaccurately associated with hypothyroidism and increased TSH (40), whereas many individuals from iodine-deficient areas are clinically euthyroid (41) and their TSH is not elevated because their circulating $\mathrm{T}_{3}$ is normal, or even slightly elevated, as the immediate consequence of the thyroid's autoregulatory mechanisms $(38-39,42)$. These misconceptions are likely to be the result of different causes. The important role played by TSH-independent autoregulation is often overlooked, or actually not known to younger Westerntrained physicians. Moreover, no clear distinction was made between the iodine deficiency disorders (IDD) reported in areas of iodine deficiency alone and those reported from regions where other additional factors, such as goitrogens and/or selenium deficiency, result in atrophy of the thyroid and overt clinical and biochemical hypothyroidism $(43,44)$. With uncomplicated iodine deficiency, overt signs and symptoms of clinical or subclinical hypothyroidism (increased serum TSH) are not observed, because many tissues derive their intracellular $\mathrm{T}_{3}$ from their normal or slightly elevated circulating $\mathrm{T}_{3}$. But it does not mean that these euthyroid individuals might not suffer from selective hypothyroidism of organs, such as the brain, that derive an important part of the intracellular $\mathrm{T}_{3}$ by local deiodination from $\mathrm{T}_{4}(40,45-46)$. The iodine-deficient fetuses and newborns are an important exception, because thyroid autoregulation is not yet fully operative (47) and they are clinically and subclinically hypothyroid, as is described in more detail later.

The condition presenting with a decrease in plasma $\mathrm{T}_{4}$, without an increase in circulating TSH, has been termed hypothyroxinemia (46), and for this reason we shall refer to iodine-deficient individuals and animals as hypothyroxinemic, not as hypothyroid. This assumes that their tissues would be hypothyroxinemic, but that the tissue concentrations of $\mathrm{T}_{3}$ would be normal, or even elevated. However, this is not necessarily so, as extrathyroidal adaptive mechanisms involving the different responses of the iodothyronine deiodinases (D1, D2, and D3) to changes in the availability of $T_{4}$ and $T_{3}$, exert a further important role $(1,3,32)$.

\section{Role of the iodothyronine deiodinase isoenzymes}

The mechanisms of maintenance of $\mathrm{T}_{3}$ include changes in the deiodinases (D1, D2, and D3), which respond to the hypothyroxinemia present in tissues of the adult iodine-defi- 
cient rat $(23,30-31)$. As expected D2 activities increase in cerebral cortex $(24,25,31,48)$, cerebellum, brown adipose tissue $(23,24,30)$ and pituitary $(30)$, while D1 decreases in liver, kidney, lung, and pituitary and increases in the thyroid (24; unpublished results). The decrease in D1 activity in liver is not observed with milder iodine deficiency $(23,25)$.

An important point regarding the maintenance of plasma $\mathrm{T}_{3}$ within normal levels is whether, or not, mechanisms are involved, other than the preferential synthesis of $\mathrm{T}_{3}$ by autoregulation. This was investigated (23) comparing the thyroidal and hepatic D1 and brown adipose tissue D2 in rats on LID. D1 was increased in the thyroid, which seems to be the main source of serum $T_{3}$, as the liver D1 activities hardly changed, and it is unlikely that the increased brown adipose tissue activities contribute to the maintenance of normal serum levels in LID rats (23).

Moreover, the deiodinases are selenoenzymes and therefore a nutritional deficiency of selenium will influence the thyroid status in iodine deficiency. Selenium deficiency leads to decreases of liver D1 and D3 (31), more pronounced than those induced by iodine deficiency. The combined deficiency of selenium and iodine does not lower the increased D2 activity in brain (31), possibly because of the different selenium content in liver and brain.

\section{Severe iodine deficiency}

In severely iodine-deficient rats, the brain is $\mathrm{T}_{3}$-deficient and biologic end points of thyroid hormone action are affected, such as the density and distribution of dendritic spines of the pyramidal neurons from the visual cerebral cortex (21), in agreement with the decrease of $\mathrm{T}_{3}$ in the nuclear fraction. This was to be expected, considering the importance of $T_{4}$ for local generation of $T_{3}$ in the brain. Less expected was the finding that in severely iodine-deficient adult rats, other tissues considered as mostly dependent on plasma-derived $T_{3}$ for their intracellular $T_{3}$, were also $T_{3}$-deficient (49) and functionally hypothyroid, despite circulating $\mathrm{T}_{3}$ that was still normal. Several end points of thyroid hormone action were, for instance, affected in the liver, such as $\alpha$-glycerophosphate dehydrogenase and malic enzyme activities (20) in accordance with the decreased $\mathrm{T}_{3}$ in the nuclear fraction. The growth hormone $(\mathrm{GH})$ content of the pituitary was also decreased (20). In general, it might be concluded that in severely iodine-deficient adult rats, a normal circulating $\mathrm{T}_{3}$ does not necessarily mean that all tissues that are mostly dependent on serum-derived $\mathrm{T}_{3}$ are actually euthyroid.

\section{Heterogeneity of cerebral structures}

Of great interest are the distributions of D2 and D3 in the different areas of the brain, that are not homogeneous. The expression of D2 is more intense in the hypothalamus (tanycytes and median eminence) and pituitary (50-54), with transient increases having also been described in the mouse cochlea at postnatal day 7 (55). The most extensive up-todate study regarding the expression and activities of D2 and D3 in different brain areas of the iodine-deficient adult rat is that of Peters et al. (56). Using in situ hybridization techniques they have shown that iodine deficiency increases D2 mRNA and D2 activity, especially in cerebral cortex, medial basal hypothalamus, cerebellum, hippocampus, and pituitary, whereas D3 mRNA and activity decrease, especially in cerebral cortex, hippocampus, and cerebellum. Whereas reductions of D3 expression and activity in different regions of the iodine-deficient rat brain were of a similar magnitude, a great discrepancy was systematically observed between the increases in D2 expression and D2 activities. The latter increases greatly exceeded those expected from the changes in D2 mRNA, drawing attention to the important contribution of posttranslational effects of the low intracellular $\mathrm{T}_{4}$ of the iodine-deficient animal. The mechanism by which $\mathrm{T}_{4}$, the preferred substrate for D2, reduces its protein levels is the consequence of the $\mathrm{T}_{4}$-induced increase in the rate of $\mathrm{D} 2$ ubiquitination and subsequent proteosomal degradation (57). Thus, when $\mathrm{T}_{4}$ falls, as is the case in iodine deficiency, the D2 half-life is prolonged and the D2 activities exceed those expected from the increase in D2 mRNA. All the changes described (56) would result in a higher production of $\mathrm{T}_{3}$ from $\mathrm{T}_{4}$ (through increased $\mathrm{D} 2$ activity), enhanced by the reduced degradation of $\mathrm{T}_{3}$ and $\mathrm{T}_{4}$ (through decreased D3), all tending to mitigate in the brain the effects of the hypothyroxinemia caused by iodine deficiency by maintening normal intracellular $\mathrm{T}_{3}$ concentrations. However, how successfully this is achieved in different cerebral regions was not assessed. It will depend on the respective availability of the substrate, $\mathrm{T}_{4}$, and therefore ultimately on the degree of iodine-deficiency.

\section{lodine Deficiency Early in Development}

Iodine deficiency is a worldwide public health problem and the most important cause of preventable mental retardation. Approximately 1000 million people are living in conditions of chronic iodine deficiency of varying degree (58) and the World Health Organization (1990) has estimated that 20 million people are suffering from preventable brain damage.

There are several situations in which alterations of the central nervous system (CNS) have been related to impairment of the thyroid function during fetal development (for reviews see Morreale de Escobar et al. [32],46]. Among the different conditions the most severe damage in the CNS is found in neurologic cretinism, associated with severe iodine deficiency during the first trimester of pregnancy. The damage can only be avoided by supplying adequate amounts of iodine to the mother, before or early in pregnancy. Neurologic cretinism is a more severe condition than congenital hypothyroidism and is irreversible by birth, at which time the administration of iodine, or thyroid hormone, is no longer fully effective.

The severe neurologic manifestations in endemic cretinism point to CNS damage that has occurred early during fetal life. The most frequent alterations are deafness; motor deficits such as spasticity, trunk rigidity, flexion dystonia and muscle wasting; and mental deficiency (intellectual and visuomotor integration deficits, autism, vacuity) $(59,60)$. Some of them, such as the loss of hearing, point to damage in the cochlear development occurring during the first trimester of pregnancy. Mild and moderate degrees of iodine deficiency are also adverse for the outcome of the pregnancy (61). For years it was difficult to understand the role of thyroid hormones during early periods in which the fetal thyroid function is still not functional, but today much experimental evidence points to the role of the maternal thyroid 
hormones in early brain development during fetal life. Over the last 20 years animal experiments carried out in several laboratories have obtained evidence for a role of the maternal thyroid hormones, and very especially of $\mathrm{T}_{4}$, during early fetal development.

\section{Thyroid hormones and deiodinases before onset of fetal thyroid hormone secretion}

The evidence derived from the rat model may be summarized as follows.

$\mathrm{T}_{4}$ and $\mathrm{T}_{3}$ are found in embryonic and fetal tissues $(62,63)$ before the onset of the fetal thyroid secretion that in the rat starts at 17.5-18 days of gestation. The earliest day tested is 9 days of gestation, which is 4 days after implantation, and these concentrations remain constant until the onset of fetal thyroid secretion. Functional nuclear $\mathrm{T}_{3}$ receptors are also detected in the fetal rat brain by 14 days of gestation (64), by in situ hybridization the $\operatorname{TR} \alpha_{1}$ isoform is present in the fetal brain at 14 days of gestation (65) and the TR $\beta_{1}$ at 11.5 days of gestation in the neural tube. The $\beta_{1}$ and $\beta_{2}$ transcripts are already detected at 12.5 days of gestation in an area that will be very important for the auditory system $(66,67)$. The expression of the TR isofoms suggests important roles of thyroid hormones in specific areas during brain development.

The $\mathrm{T}_{4}$ and $\mathrm{T}_{3}$ found in the early embryos are of maternal origin, because their concentrations are very low in the case of maternal hypothyroidism $(63,68)$ and in the fetuses from mothers fed an LID (69). Figure 1 compares the $T_{4}$ and $T_{3}$ concentrations in embryotrophoblasts, placentas, and embryos found in fetuses from mothers on LIDs before the onset of fetal thyroid function. $\mathrm{T}_{4}$ and $\mathrm{T}_{3}$ are very low in embryotrophoblasts, embryos and placentas obtained from LID mothers compared to their respective controls (similar to the
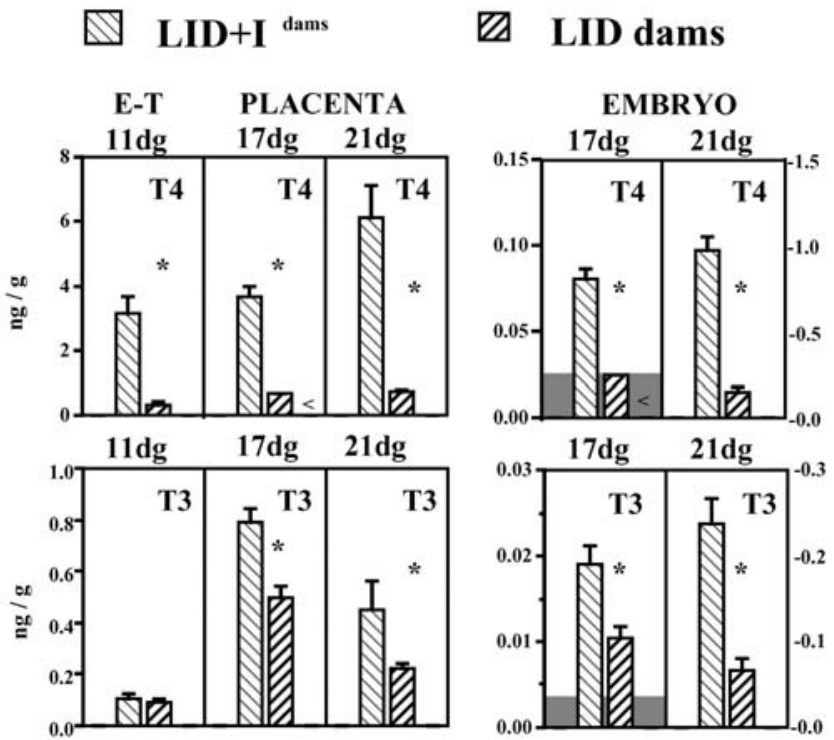

FIG. 1. Thyroxine $\left(\mathrm{T}_{4}\right)$ and triiodothyronine $\left(\mathrm{T}_{3}\right)$ concentrations (means \pm standard error of the mean [SEM]) in embryotrophoblasts (E-T), placentas and embryos from dams fed iodine-deficient (LID) and iodine-supplemented (LID I) diets. The dotted areas at the bottom of each panel indicate the limits of detection of the $\mathrm{T}_{4}$ and $\mathrm{T}_{3}$ assays. Data are from Escobar del Rey et al. (69).

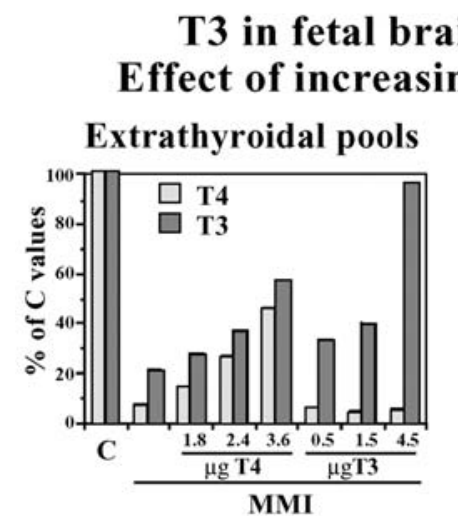

d whole fetus Effect of increasing doses of T4 and T3 Extrathyroidal pools Fetal Brain

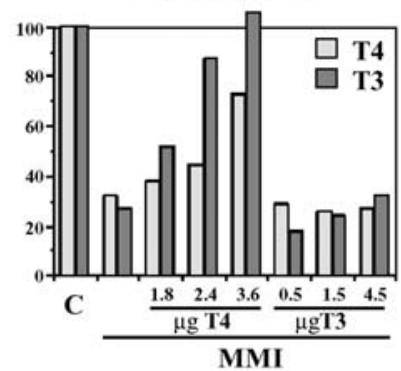

FIG. 2. Changes in the concentrations of thyroxine $\left(\mathrm{T}_{4}\right)$ and triiodothyronine $\left(\mathrm{T}_{3}\right)$ in 21-day-old fetuses from normal $(\mathrm{C})$ and 2-mercapto-1-methylimidazole (MMI)-treated dams, infused with placebo or increasing amounts of $\mathrm{T}_{4}$ or $\mathrm{T}_{3}$ (doses are $\mu \mathrm{g} / 100 \mathrm{~g}$ of body weight [BW] per day). The extrathyroidal pools comprise the amounts of $\mathrm{T}_{4}$ and $\mathrm{T}_{3}$ in the whole fetus, after dissecting out the thyroid. Data are given as percentage of values in normal (C) fetuses. The daily dose of 2.4 $\mu \mathrm{g} \mathrm{T} \mathrm{T}_{4}$ per $100 \mathrm{~g} \mathrm{BW}$ was adequate to maintain maternal euthyroidism. It was not sufficient to ensure normal $T_{4}$ and $T_{3}$ pools of the fetus as a whole, or $\mathrm{T}_{4}$ of the fetal brain, but was enough to ensure normal brain $\mathrm{T}_{3}$ in the brain of the MMIfetuses. The infusion of $\mathrm{T}_{3}$ at a daily dose of $0.5 \mu \mathrm{g}$ per 100 g BW maintained maternal euthyroidism but did not ameliorate fetal brain $\mathrm{T}_{3}$ deficiency. Data are from Calvo et al. (72).

findings in embryonic structures from thyroidectomized (Tx) mothers).

\section{Thyroid hormones and deiodinases after onset of fetal thyroid hormone secretion}

Maternal transfer in normal and hypothyroid conditions. The maternal transfer of thyroid hormones continues until birth. At term the contribution of the mother represents approximately $20 \%$ of the total extrathyroidal pool of fetal $\mathrm{T}_{4}$ in the rat (70), and up to $50 \%$ of serum $\mathrm{T}_{4}$ in the human fetus $(40,71)$. The amount of $\mathrm{T}_{4}$ tranferred, although not enough to prevent thyroid hormone deficiency in all the tissues of the rat fetus at term, is enough to avoid the cerebral $\mathrm{T}_{3}$ deficiency until birth in the case of fetal hypothyroidism (72). This was demonstrated in experiments in which hypothyroid rat dams on 2-mercapto-1-methylimidazole (MMI) were infused with increasing doses of $\mathrm{T}_{4}$ or $\mathrm{T}_{3}$. The main findings are illustrated in Figure 2, which compares the $\mathrm{T}_{4}$ and $\mathrm{T}_{3}$ concentrations reached in extrathyroidal pools and in the fetal brain: A dose of $2.4 \mu \mathrm{g} \mathrm{T}_{4}$ infused to the mother normalizes $\mathrm{T}_{3}$ in the fetal brain, even when $\mathrm{T}_{4}$ in fetal brain is only $50 \%$ that of control. This is an experimental situation of interest for human congenital hypothyroidism, where the maternal contribution of $\mathrm{T}_{4}$ would avoid the cerebral $\mathrm{T}_{3}$ deficiency of the fetuses, protecting their brain until birth. As may be seen for the rat in Figure 2, cerebral $\mathrm{T}_{3}$ remains low, despite an increase in circulating levels in the fetuses from the dams infused with high $\mathrm{T}_{3}$ doses. These findings confirm that the fetal rat brain derives all its $\mathrm{T}_{3}$ by local generation from $\mathrm{T}_{4}$, and none from circulating $\mathrm{T}_{3}$. 
In the fetus the protection of the brain by $\mathrm{T}_{4}$ is achieved through the increase in the type II deiodinase (D2) activity in response to the low circulating and cerebral levels of $\mathrm{T}_{4}(72,73)$. The increased D2 activity produces more or less $\mathrm{T}_{3}$ depending mostly on the amount of available substrate $\left(\mathrm{T}_{4}\right)$, whether the latter is of fetal or maternal origin. Therefore, during early fetal development an adequate supply of maternal $\mathrm{T}_{4}$ is of primary importance, whichever the circulating levels of $T_{3}$.

Fetal thyroid status in normal conditions. There is a large increase in the thyroidal $\mathrm{T}_{4}$ and $\mathrm{T}_{3}$ pools from 18 days of gestation until birth (100- and 400-fold, respectively) (74). As a consequence of this and of the continuing maternal transfer there is a 9-fold increases in the circulating $\mathrm{T}_{4}$, as well in most tissues, organs, and in the total extrathyroidal pool. In contrast, the circulating $T_{3}$ levels do not increase $T_{3}$ concentrations, however, do increase in many fetal tissues and in the extrathyroidal pool and do so at different rates (74), except for the liver $\mathrm{T}_{3}$, which increases only 2- to 3-fold.

The changes in plasma and brain are shown in (Fig. 3, left). The concentrations of $T_{4}$ and $T_{3}$ in fetal brain increase very

Fetal Brain and Plasma
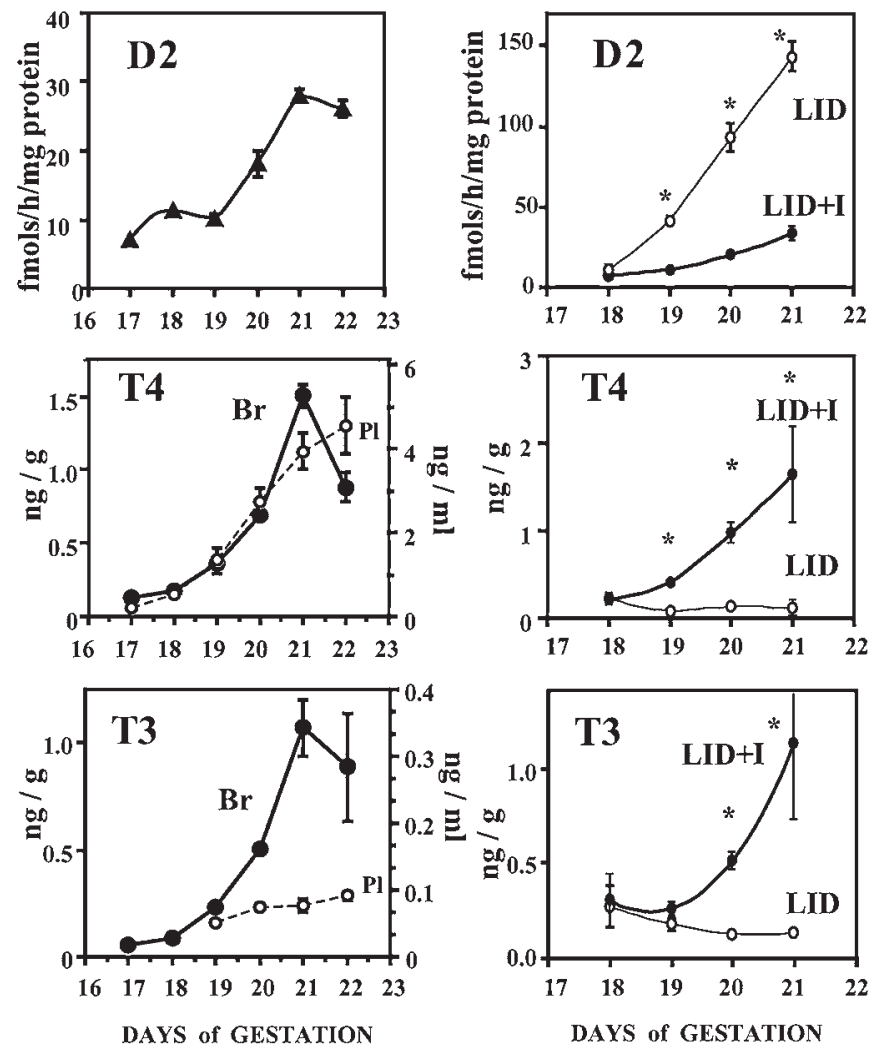

FIG. 3. Left: Type 2 iodothyronine deiodinase (D2) activities and concentrations of thyroxine $\left(\mathrm{T}_{4}\right)$ and triiodothyronine $\left(\mathrm{T}_{3}\right)$ in the brain of rat fetuses between onset of thyroid function $(17 \mathrm{dg})$ and birth $(22 \mathrm{dg})$. The $\mathrm{T}_{4}$ and $\mathrm{T}_{3}$ concentrations in fetal plasma are also depicted. Data are from Ruiz de Oña et al. (73). Right: Concentrations of $T_{4}$ and $T_{3}$ and D2 activities in the brain of rat fetuses (18-21 dg) from mothers on an iodine-deficient (LID) and iodine-supplemented $(\mathrm{LID}+\mathrm{I})$ diets. Data are from Obregon et al. (24). Data are mean \pm SEM standard error of the mean (SEM). quickly during the last 4 days before birth $(73,74)$ (Fig. 3, left). Brain $\mathrm{T}_{4}$ increases 9-fold in parallel with plasma $\mathrm{T}_{4}$, though at a quicker rate suggesting an increased uptake of $\mathrm{T}_{4}$ by the fetal brain. The increase of $\mathrm{T}_{3}$ (18-fold) is the result of the ontogenic increases in D2 activities that locally provide the $\mathrm{T}_{3}$ required for the fetal brain. This is in contrast to the low increases in liver $\mathrm{T}_{3}$ and D1 (not shown).

The amount of $\mathrm{T}_{4}$ available to the fetus, whether of maternal or fetal origin, plays a limiting role for the local generation of $\mathrm{T}_{3}$ in the fetal brain. Cerebral D2 activity is able to respond to hypothyroidism (MMI) as early as day 17 of gestation (73), that is, before the onset of fetal thyroid secretion. The increases in D2 activities are small at the earlier times tested (2-fold at 17 days' gestation) but increase later on (at 19-22 days' gestation). The presence of D2 in fetal brains earlier in gestation (10-16 days gestation) remains to be identified, it might be located in specific brain nuclei only visible by in situ hybridization techniques. D2 activities in rat fetal brain and its responses to hypothyroidism are similar to those found in adult brain, suggesting that the deiodinative mechanisms are fully operative.

Fetal thyroid status in iodine deficiency. The impact of iodine deficiency for the fetal and early neonatal brain is illustrated in Figure 3, right, and Figure 4, in which thyroid hormone concentrations and D2 activities in fetal and neonatal brain of fetuses and pups on LID are represented at the end of gestation and during the postnatal period comprising the first 4 weeks of life (24). During the fetal period (Fig. 3 , right) there is a large increase in D2 activity in response to iodine deficiency. It is not, however, able to increase $\mathrm{T}_{3}$ in the fetal brain because of the very low concentration of $\mathrm{T}_{4}$, which is its only source of cerebral $T_{3}$. The situation is different during the postnatal period (Fig. 4). The little iodine that is available to the dam is concentrated in the milk, because the mammary gland competes efficiently with the maternal thyroid to concentrate iodine, thus providing an increased amount of iodine to the lactating pups (24). This leads to a small increase in the circulating and brain $\mathrm{T}_{4}$ (to $25 \%-35 \%$ of LID + I pups) that, together with the dramatic increase in D2 activity, produces $\mathrm{T}_{3}$ in amounts similar to those found in the brain of iodine-sufficient pups (LID + I). The pattern of changes of brain $\mathrm{D} 2, \mathrm{~T}_{4}$, and $\mathrm{T}_{3}$ shows two clear peaks, one at the end of the fetal period and a second one 2 weeks after birth, which are coincident with important periods of brain development, occurring both in the LID and LID + I pups.

Other fetal tissues also showed signs of clear hypothyroidism. D1 activities were reduced in liver and lung of LID fetuses, even when the activities were very low compared to those of adult rats, while BAT D2 increased sevenfold in LID fetuses at term (24), up to levels found in cold-exposed rats. The fetal skin is another source of $\mathrm{T}_{3}$ with increased D2 activities during iodine deficiency (48). D3 activities decreased in fetal skin of LID fetuses at the end of gestation (48). Until now, no changes in the placental D2 and D3 have been reported in response to iodine deficiency. The fetal thyroid responds to mild and severe iodine deficiency with increases in the expression of sodium iodide symporter (NIS) and D1 mRNA (75). The expression of NIS was also found in the fetal side of the placenta and was increased in LID fetuses (75), suggesting the participation of the pla- 
BRAIN FETAL and NEWBORN RATS
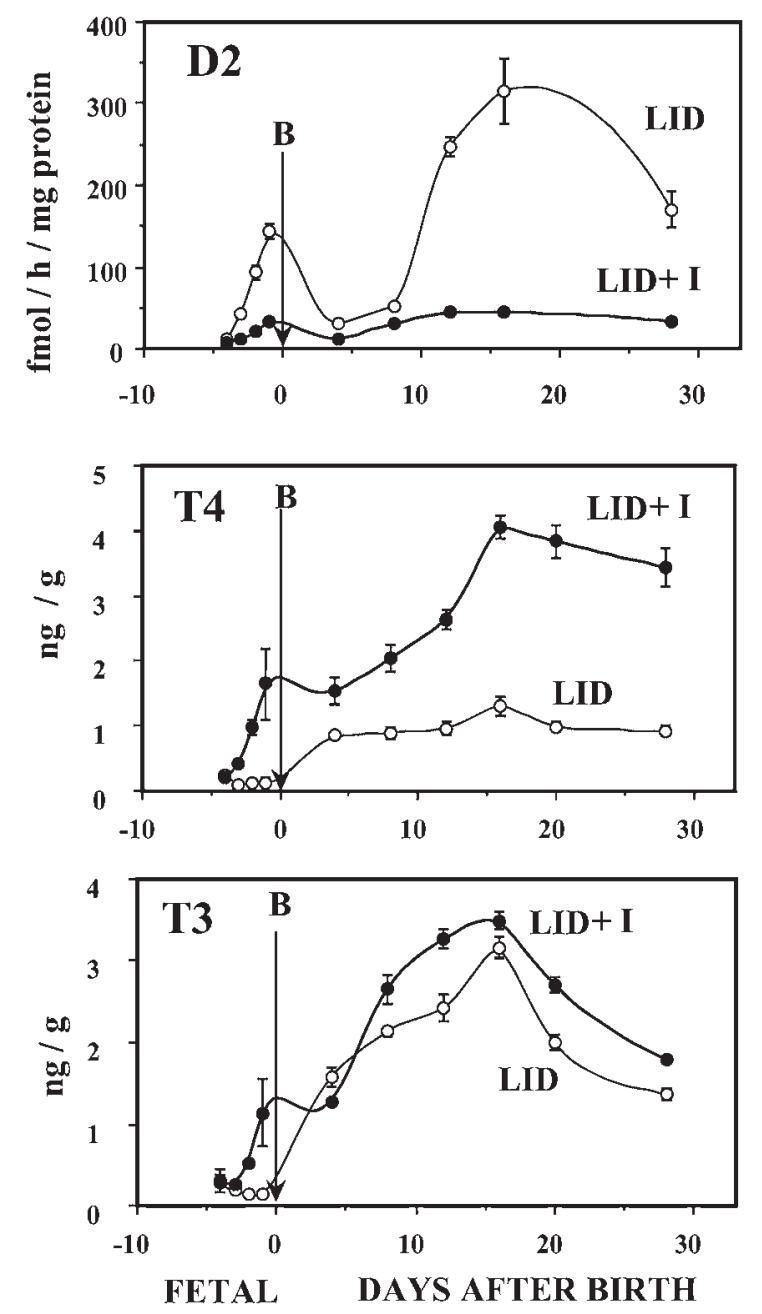

FIG. 4. Concentrations of thyroxine $\left(\mathrm{T}_{4}\right)$ and triiodothyronine $\left(T_{3}\right)$, and type 2 iodothyronine deiodinase (D2) activities in the brain of rat fetuses and pups until 4 weeks of postnatal age born from mothers on an iodine-deficient (LID) and iodine-supplemented (LID + I) diet. The data shown "before" birth are the same of Figure 3. Data (mean \pm standard error of the mean [SEM]) are from Obregon et al. (24).

centa in the iodine-concentrating mechanisms functioning during gestation.

In summary, the consequences of iodine deficiency during gestation are as follow: the transfer of maternal thyroid hormones to the fetus is very low during the early period of gestation, because the mother is hypothyroxinemic. During the final period of gestation the maternal transfer continues to be very low and the fetus is unable to produce enough $\mathrm{T}_{4}$ for the normal brain development, because of the shortage of iodine. After birth iodine is concentrated in the milk and increases the iodine available to the suckling pup's thyroid, as well as the circulating and brain $\mathrm{T}_{4}$ that, combined with the increased $\mathrm{D} 2$ activity, is able to mitigate the $\mathrm{T}_{3}$ deficiency observed in the neonatal brain.
Irreversible neurologic abnormalities

Evidence from experimental animals. Several neurologic abnormalities have been demonstrated in rats born from mothers fed markedly iodine-deficient LID diets for one or two generations $(76,77)$. The behavioral defect found is the susceptibility to audiogenic seizures, associated with hearing defects typical of neurologic cretinism. We have recently confirmed this in the progeny of mothers on LID, and the defect is irreversible, even when the iodine deficiency is corrected during adult life, strongly suggesting that an early deficiency in maternal $\mathrm{T}_{4}$, leading to decreased fetal brain $\mathrm{T}_{3}$, induces irreversible alterations in cerebral development.

Many morphologic end points of development of the cerebral cortex, hippocampus, and cerebellum have been reported in the progeny from dams chronically on LID (i.e., see Martinez-Galan et al. [78] for the rat and Hetzel [3] for the sheep and marmoset). Recently we have shown that maternal hypothyroxinemia restricted to early stages of development affects neurogenesis irreversibly. Two models have been studied: the iodine-deficient rat dams (LID model) (79) and dams (3d-MMI model) that were treated for only 3 days with a goitrogen (2-MMI), which resulted in a transient and moderate maternal thyroid hormone deficiency (80). In both models the dams were hypothyroxinemic without being hypothyroid during the period of active corticogenesis and migration of radial neurons into the developing cerebral cortex and hippocampus. This developmental phase occurs when the mother is the only source of thyroid hormone available to the fetus. The final location of those cells generated during early periods of neurogenesis was determined in the young rats. The cells were labeled with bromodeoxyuridine (BrdU), injected into the dams during gestation (between embryonic day 14-16 or embryonic day 17-19), when two major waves of radial migration of neurons into the somatosensory cortex are taking place. With both models the migration of the BrdU-immunoreactive cells, most of which were neurons, was affected, with neurons appearing in aberrant locations, such as the subcortical white matter, and in cortical and hippocampal layers inappropriate for their date of birth. The proportion of neurons reaching the outer layers of the somatosensory cortex was clearly decreased. Cytoarchitectural changes were also evidenced in the hippocampus and barrel cortex of the primary somatosensory cortex. Maintenance of maternal hypothyroxinemia throughout pregnancy (LID model) was not necessary for the appearance of these abnormalities, as only a short period of maternal thyroid hormone deficiency between embryonic day 12-15 (3d-MMI model) was sufficient to derange the radial migration of neurons generated between embryonic day 14-16 and those generated between embryonic 17-19, as well as the cytoarchitecture of the hippocampus and barrel cortex. In the 3d-MMI model the maternal thyroid hormone deficiency was quite moderate and limited to a very precise window during development. Correction of the moderate maternal thyroid hormone insufficiency by infusion of $\mathrm{T}_{4}$ during MMI treatment prevented the alterations of radial neuronal migrations and cytoarchitecture described above, whereas $\mathrm{T}_{4}$ infusion was of no benefit when delayed beyond this critical period of corticogenesis. An unexpected finding was the induction of behavioural alterations in the pups born to the treated dams 
of the 3d-MMI model: an increased susceptibility to respond with wild runs to acoustic stimulation.

Such experimental findings clearly support that an adequate supply of maternal thyroid hormone is very important for the early neurodevelopment of the fetus. If relevant to humans, they might help to define the period in human gestation when the fetal cerebral cortex is especially sensitive to changes in the availability of maternal thyroid hormone. In humans, the radial migrations of neurons into the cortex take place mostly between the 8th and 24th weeks postconception, with two main waves peaking at the 9th and 12th weeks, namely at 11 and 14 weeks postmenstrual age (PMA). The first one coincides approximately with the peak of the maternal human chorionic gonadotropin (hCG)-driven serum free $\mathrm{fT}_{4}$ surge.

Evidence from studies in humans. Most of the evidence indicating that early maternal hypothyroxinemia caused by iodine deficiency affects early brain development in human has been obtained from abundant epidemiologic associations obtained from population studies, and has been considered indirect evidence. Very recently, however, an important observation has been published that constitutes direct proof, because the evidence has been obtained by pairing data on the neurodevelopment of the child with maternal thyroid status early in pregnancy. Vermiglio et al. (81) have found a statistically significant correlation between the IQ of the child at 9-10 years of age and the maternal thyroxinemia during the first (but not later) trimester of pregnancy. Both the early maternal hypothyroxinemia and the decrease in IQ were relatively moderate, as was the degree of iodine deficiency, but $70 \%$ of the children from the early hypothyroxinemic mothers and $0 \%$ of nonhypothyroxinemic mothers were diagnosed as having attention deficit hyperactivity disorder (ADHD).

\section{The human fetal brain}

Although for many years the human fetus has been considered to develop in the absence of thyroid hormones, there is increasing evidence that most of the findings summarized here for rat in experimental models might be applied to man.

We now have evidence that in the human fetuses $T_{4}$ is found in fluids from the embryonic cavities (coelomic and amniotic cavities) during the first trimester of gestation. $\mathrm{T}_{4}$ in coelomic fluid, and later in fetal plasma, is correlated positively with maternal plasma $\mathrm{T}_{4}(82,83)$. Both $\mathrm{T}_{4}$ and $\mathrm{T}_{3}$ and the nuclear TRs are found in the human fetal brain by the end of the first trimester of gestation and increase 10 -fold by 18 weeks' gestation $(84,85)$. The expression of $\operatorname{TR} \alpha$ and $\operatorname{TR} \beta$ isoforms has been recently reported in the cerebral cortex of first trimester fetuses (8-14 weeks) $(86,87)$.

$\mathrm{T}_{4}$ and $\mathrm{T}_{3}$ are found in cerebral cortex, liver and lung of human fetuses of $8-18$ weeks' PMA $(84,85)$. The ontogenic patterns of $\mathrm{T}_{4}, \mathrm{~T}_{3}, \mathrm{rT}_{3}, \mathrm{D} 2$ and $\mathrm{D} 3$ activities in nine different cerebral areas from fetuses of 13,20 weeks PMA have recently been reported (88). They showed spatial- and temporalspecificity with divergence between the cerebral cortex and other cerebral areas, such as the cerebellum, as illustrated in Figure 5. The concentrations of $\mathrm{T}_{4}, \mathrm{~T}_{3}$, and the activity of D2, increase with age in the cortex between 13-20 weeks PMA, whereas $\mathrm{rT}_{3}$ (not shown) decreases. D3 activity is very low.

\section{HUMAN FETUS}
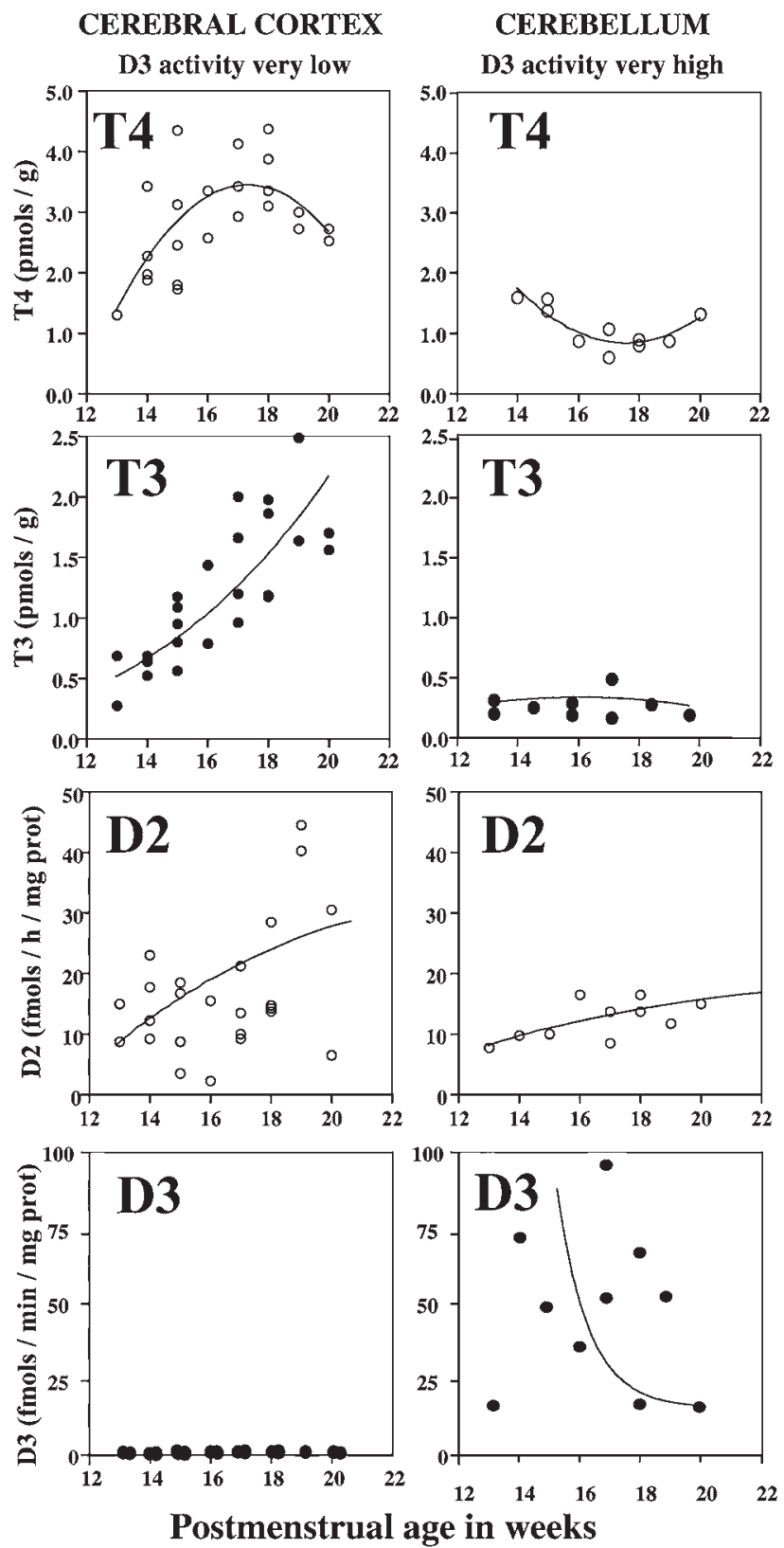

FIG. 5. Ontogenic changes in the concentrations of thyroxine $\left(\mathrm{T}_{4}\right)$, triiodothyronine $\left(\mathrm{T}_{3}\right)$, type 2 and 3 iodothyronine deiodinases (D2 and D3) activities in the human fetal cerebral cortex and cerebellum from 13th weeks up to midgestation. During this period $\mathrm{T}_{4}$ in the fetal serum increases approximately fivefold and circulating $\mathrm{T}_{3}$ remains very low. Data are from Kester et al. (88).

In the cerebellum D3 activities are very high, $\mathrm{T}_{3}$ concentrations are low, and $\mathrm{T}_{4}$ does not increase. Concentrations of $\mathrm{rT}_{3}$ (not shown) are higher than in cerebral cortex. Other regions also have high D3 activities (brain stem, spinal cord, midbrain) and low $\mathrm{T}_{3}$ concentrations. These findings support the need of $\mathrm{T}_{3}$ by the human cerebral cortex before midgestation, when the mother is the sole source of precursor $\mathrm{T}_{4}$ and confirm the importance of D2 and D3 in determining 
the local availability of $\mathrm{T}_{3}$ at the appropriate timing. Others have also reported the expression of D2 in fetal cerebral cortex as early as 7-8 weeks PMA with a peak at 15-16 weeks (89). Results so far confirm the important roles of D2 and D3 in the local bioavailability of cerebral $\mathrm{T}_{3}$ during fetal life: D2 generates $T_{3}$ from $T_{4}$ and $D 3$ protects brain regions from excessive $T_{3}$ until differentiation is required. This is in conceptual agreement with a recent report in Xenopus laevis showing that D2 is present at the precise time that a given tissue responds to $\mathrm{T}_{3}$-induced metamorphosis (90), being the deiodination of $\mathrm{T}_{4}$ a precise requirement in this process.

To our knowledge there is only one report from Karmarkar et al. (1993) that analyzes the effect of iodine deficiency in human fetal brain. They measured $\mathrm{T}_{4}, \mathrm{~T}_{3}, \mathrm{rT}_{3}, \mathrm{D} 2$, and $\mathrm{D} 3$ in the cerebral cortex of human fetuses (11-25 weeks' gestation) from women with mild to moderate iodine-deficiency mothers and in fetuses from iodine-sufficient mothers (91). $\mathrm{T}_{4}$ and $\mathrm{T}_{3}$ concentrations peaked at 15-18 weeks' gestation and then decreased in fetuses from iodine-sufficient groups, while in mild iodine deficiency $\mathrm{T}_{3}$ concentrations were maintained at a higher level until week 22, although they were always lower than in the iodine-sufficient group. $\mathrm{rT}_{3}$ rose from 11 to 22 weeks' gestation with no effect of iodine status. D2 and D3 activities increased from 11 to 22 weeks' gestation, and D2 increased further in mild and moderate iodine deficiency, whereas D3 activity was significantly decreased. It appears interesting that D2 activity had not yet increased in response to the lower $\mathrm{T}_{4}$ at 11-14 weeks' gestational age, suggesting that downregulation of $\mathrm{D} 2$ activity by $\mathrm{T}_{4}$ is delayed with respect to the onset of its expression. It did so later, at 15-18 weeks, but was, however, inadequate because $T_{3}$ in the cortex remained low in iodine-deficient conditions. Therefore, cerebral cortex D2 and D3 activities are modulated in iodine deficiency to enhance $\mathrm{T}_{3}$ production from $\mathrm{T}_{4}$ during the period of active corticogenesis in the human brain.

There is increasing evidence of the expression of the deiodinases in the utero-placental unit and D3 in the fetal epithelia $(92,93)$, but their possible alterations in iodine-deficient conditions are unknown.

\section{Adaptation to Different Degrees of lodine Deficiency}

We have already pointed out in the introduction that it is very difficult to compare results from the many studies carried out in rats fed diets with "a low iodine content," especially because its actual iodine content is usually not reported, and because of the many other confounding factors, other than iodine intake, that may affect the findings. From the survey of results from animal experiments and epidemiologic reports in humans, it may be concluded that the actual degree of the iodine deficiency is crucial for the final results, with both intrathyroidal and extrathyroidal mechanisms contributing differently according to the availability of this micronutrient.

We have recently attempted to define the sequence of intrathyroidal and extrathyroidal adaptations to different degrees of iodine deficiency in young adult female rats fed for 3 months with the same Remington-type LID diet. On the basis of an intake of $20 \mathrm{~g} / \mathrm{d}$, this diet provided $0.06 \mu \mathrm{g}$ I. Different groups received the same diet, supplemented with added potassium iodide to provide a further $0.5,1.0$, and 5.0 $\mu \mathrm{g}$ of iodine per day. Another group, LID, was fed LID to which minute amounts of $\mathrm{KClO}_{4}(0.005 \%)$ were added to inhibit the availability to the thyroid of the small amounts of iodine contained in the diet. This amount was likely to be reduced from $0.06 \mu \mathrm{g} / \mathrm{d}$ to approximately $0.03 \mu \mathrm{g} / \mathrm{d}$. Thus, there was a more than 100-fold range of iodine intakes between the LID +5.0 and LID groups. The total weight and iodine content, $\mathrm{T}_{4}$ and $\mathrm{T}_{3}$ contents and $\mathrm{D} 1$ activities were measured in the thyroid, as well as plasma $\mathrm{T}_{4}, \mathrm{~T}_{3}$, and TSH, and $\mathrm{T}_{4}$ and $\mathrm{T}_{3}$ concentrations in 11 different tissues, and D1 or D2 activities in 4 of them. Some of the findings are illustrated in Figures 6 and 7.

Intrathyroidal autoregulatory mechanisms are already clearly effective when the iodine intake and thyroid iodine content were reduced from the LID +5.0 to the LID +1.0 groups, including a preferential secretion of $\mathrm{T}_{3}$ at the expense of $\mathrm{T}_{4}$, and an increase in thyroid weight. All these changes occur without a statistically significant increase in circulat-
A

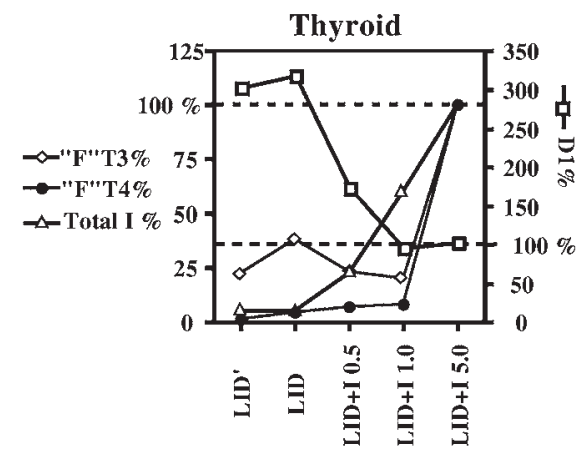

B

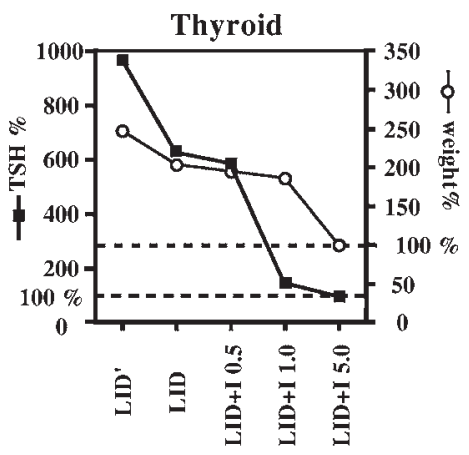

FIG. 6. Changes in the thyroid gland of adult female rats fed for 3 months with the same low-iodine diet (LID) and different iodine supplements, from 0.03 (LID' group) to $5 \mu \mathrm{g}$ of iodine per day (LID +5.0 group). (A) shows the mean total iodine, "Free" thyroxine $\left(\mathrm{T}_{4}\right)$ and "Free" triiodothyronine $\left(\mathrm{T}_{3}\right)$ contents, and D1 activities of the thyroid gland, expressed as percentage of the mean value found for the LID +5.0 group. The "Free" $\mathrm{T}_{4}$ and "Free" $\mathrm{T}_{3}$ contents correspond to the concentrations of $\mathrm{T}_{3}$ and $\mathrm{T}_{4}$ present as iodoaminoacids (not incorporated into proteins by peptidic bonds) and available for secretion. B: Thyroid weight is significantly increased without an increase in circulating thyrotropin (TSH), as well as the intrathyroid "Free" $\mathrm{T}_{3}$ to "Free" $\mathrm{T}_{4}$ ratio, without the increase in D1 observed with a more marked degree of iodine deficiency (A). 

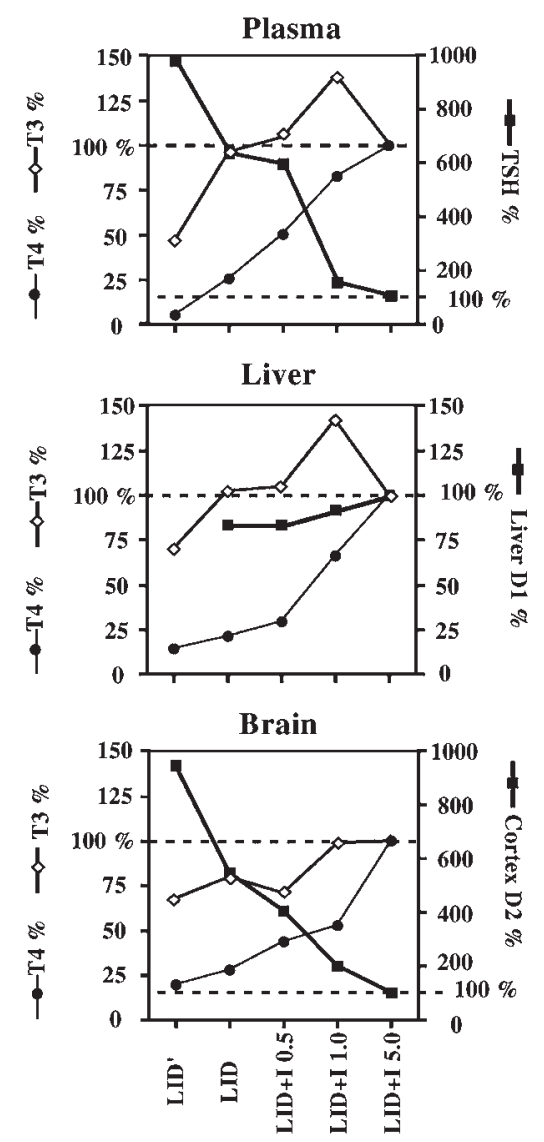

FIG. 7. Changes observed in the plasma, liver, and brain of the same rats as those of Figure 6. Consistent with the findings shown in the latter for the thyroid, the autoregulatory mechanisms triggered with the decrease in iodine intake from the LID + 5.0 to LID + 1.0 groups, there is a rapid increase of the preferential secretion of triiodothyronine $\left(\mathrm{T}_{3}\right)$ into the plasma, at the expense of thyroxine $\left(\mathrm{T}_{4}\right)$, without an increase in thyrotopin (TSH), that starts increasing in those groups with a lower iodine intake, where circulating $\mathrm{T}_{3}$ is no longer elevated. The changes in the concentrations of $\mathrm{T}_{4}$ and $T_{3}$ in the liver were consistent with those observed in the plasma, with a minor decrease of D1 in the LID +1.0 and LID groups. Despite the very marked increase in D2 activity in the brain, with increasing hypothyroxinemia, cerebral $\mathrm{T}_{3}$ started decreasing with iodine intakes between those of the LID + 1.0 and LID + 0.5 groups, although it is likely that this occurs at different degrees of iodine deficiency for different cerebral structures (56).

ing TSH. One of the extrathyroidal adaptative mechanisms, namely the increase in cerebral D2, was also triggered by this minor degree of iodine deficiency and cerebral $\mathrm{T}_{3}$ was maintained within the normal range. An increase in thyroid D1 activity does not appear to be involved in the initial autoregulatory responses, as the increase already described by others (23) was only found when iodine intake was further decreased (LID + 0.5 group) and plasma TSH had increased significantly. In this group, cerebral $\mathrm{T}_{3}$ concentrations were decreased, despite the further increase in D2, whereas liver $\mathrm{T}_{3}$ was still normal, and only decreased with the most extreme iodine deficiency (LID group). Although not illustrated here, some tissues (i.e., ovary, lung, and muscle) were able to maintain normal concentrations of $\mathrm{T}_{3}$, even in the LID group, where plasma $\mathrm{T}_{3}$ was reduced to $50 \%$ of normal values. The results of this study stress that the thyroid autoregulatory response to iodine deficiency predominates as an adaptative mechanism when the individual is faced with moderate chronic decreases of iodine intake. The extrathyroidal response of cerebral D2 activity contributes to the maintenance of adequate concentrations of $T_{3}$ in the brain. In most tissues $\mathrm{T}_{3}$ concentrations may actually increase. With a further decrease in iodine availability the thyroid autoregulatory mechanisms no longer suffice and extrathyroidal adaptation involving the iodothyronine deiodinases plays an increasingly important role, but may also become insufficient for some, but not all, tissues. The thyroid status of the iodine-deficient rat is not only dependent on the degree of iodine availability but is also tissue-specific, and this could account for the differences in reported results, even for the same species. Thus, a single answer cannot be given to the question of whether iodine-deficient individuals are euthyroid or hypothyroid, even if their plasma $\mathrm{T}_{4}, \mathrm{~T}_{3}$, and $\mathrm{TSH}$ are known, because of the involvement of metabolic pathways- mainly deiodinative- that also appear to be tissue-specific. Even with the most severe iodine deficiency that we have studied, tissues with decreased, normal or increased $\mathrm{T}_{3}$ concentrations coexist in the same animal. This contrasts with the situation encountered in cases of primary thyroid failure (thyroidectomy, treatment with goitrogens, etc.) where autoregulatory mechanisms are impaired. Thus, the involvement of the deiodinating isoenzymes in thyroid hormone metabolism and thyroid hormone status is not necessarily the same as that described in primary hypothyroidism, and has to be studied in the iodine-deficient animal in a tissue-specific manner, at different levels of iodine intake and, as we have already seen, at different stages of development.

\section{Summary}

From the present studies we conclude that iodine deficiency leads to important thyroidal and extrathyroidal adaptations aimed to maintain $\mathrm{T}_{3}$ concentrations in tissues. Many intrathyroidal autoregulatory changes occur even without an increase of circulating TSH and result in a preferential synthesis and secretion of $\mathrm{T}_{3}$. Maintenance of normal or elevated $\mathrm{T}_{3}$ at the expense of $\mathrm{T}_{4}$ maintains clinical euthyroidism, although some tissues (i.e., brain) might be selectively $\mathrm{T}_{3}$-deficient and hypothyroid. In contrast to the condition of the euthyroid iodine deficient mother, these autoregulatory adaptative mechanisms are not yet fully developed in the fetus. Its circulating $\mathrm{T}_{3}$ is very low after onset of fetal thyroid secretion, as a result of which the fetuses and newborns from iodine-deficient mothers are $\mathrm{T}_{3}$-deficient throughout gestation and clinically hypothyroid. This is why in areas of iodine deficiency TSH values at neonatal screening are higher than those of newborns from iodine-sufficient areas, and their frequency may be used as criterion for the identification of regions with varying degrees of this micronutrient deficiency.

With increasing severity of the iodine deficiency, the degree of the hypothyroxinemia also increases and autoregulatory mechanisms become insufficient for maintenance of normal $\mathrm{T}_{3}$ in the circulation and most tissues. Extrathyroidal responses involving the iodothyronine deiodinases are trig- 
gered progressively and play a crucial role in determining the thyroid hormone status in a tissue-specific fashion. There is a very important increase in the activity of D1 in the thyroid, that enhances the secretion of $\mathrm{T}_{3}$ generated from $\mathrm{T}_{4}$, and that contributes to maintenance of normal plasma $T_{3}$. Especially important for the thyroid hormone status of specific tissues, such as brain and BAT, is the interplay between the increased activity of $\mathrm{D} 2$ in response to the low $\mathrm{T}_{4}$, and the concomitant decrease in that of $\mathrm{D} 3$, sparing $\mathrm{T}_{4}$ and prolonging the half-life of intracellular $\mathrm{T}_{3}$. The final condition is not only dependent on the degree of iodine deficiency but is tissue specific. Even in rats on a very low iodine intake, that is 100-fold lower than that required for normal thyroid function, tissues with elevated, normal, and decreased $\mathrm{T}_{3}$ are found in the same animal, with biologic end points of thyroid hormone action affected accordingly.

It is quite unlikely that human populations would survive in a certain geographical area when thyroid autoregulation and other adaptative mechanisms would no longer suffice to maintain $\mathrm{T}_{3}$ within normal limits. The iodine intake in areas of severe iodine deficiency is still approximately one tenth of requirements, contrasting with the 100fold decrease that may be obtained in experimental animals. In these human populations women are severely hypothyroxinemic, but maintain euthyroidism at the expense of normal plasma $\mathrm{T}_{3}$ levels, despite which fetal neurodevelopment may be more or less severely compromised. When unable to do so and both circulating $\mathrm{T}_{4}$ and $\mathrm{T}_{3}$ are low, fetal loss is the outcome, and populations would eventually abandon the area, or disappear. Thus, findings from severely iodinedeficient animals should not be extrapolated to the human situation without taking into account the degree of hypothyroxinemia and whether, or not, circulating $T_{3}$ is still normal.

Iodine deficiency, and especially that of the pregnant woman, is still at the beginning of the third millenium, the major cause of mental retardation worldwide, affecting millions to a greater or lesser degree. Despite the many sustained efforts of many international institutions, such as UNICEF, World Health Organization, and International Council for the Control of Iodine Deficiency Disorders (ICCIDD), this human scourge still exists, despite the ease with which iodine-deficiency disorders can be avoided by providing sufficient iodine to the whole population, and extra iodine supplements during pregnancy and lactation. Europe is far behind other continents in these efforts and there is recent evidence that an increasing proportion of North American pregnant women do not receive the optimal amounts of iodine and require supplementation.

Remember that despite all the intrathyroid and extrathyroidal mechanisms in which iodothyronine deiodinases play a very important role, they may be insufficient to protect the brain in iodine deficiency, and the utmost efforts are needed to comply worldwide-including industrialized societies-with the following basic human rights:

1. Every child has the right to an adequate supply of iodine to ensure his (or her) normal development. Of particular importance in this context is the right of the unborn child.

2. Every mother has the right to an adequate iodine nutrition to ensure her unborn child experiences normal mental development.
(Declarations emanating from the Convention on the Rights of the Child, United Nations Assembly, New York, 1989; World Summit for Children, United Nations, New York, 1990.)

\section{Acknowledgments}

This is written in memory of John T. Dunn, who dedicated all his life to worldwide prevention of iodine-deficiency disorders.

This work was supported by FIS RCMN (C03/08) and PI031417 (03/1417) from Instituto de Salud Carlos III and SAF2001-2243.

\section{References}

1. Studer H, Köhler H, Bürgi H 1974 Iodine deficiency. In: Greer MA, Solomon DH (eds) Handbook of Physiology. American Physiological Society, Washington, D.C., pp. 974-980.

2. Mano MT, Potter BJ, Belling GB, Chavadej J, Hetzel BS 1987 Fetal brain development in response to iodine deficiency in a primate model (Callithrix Jacchus Jacchus). J Neurol Sci 79:287-300.

3. Hetzel BS 1994 Hormone nurturing of the developing brain: Sheep and marmoset models. In: Stanbury JB (ed) The Damaged Brain of Iodine Deficiency. Cognizant Communication Co., Elmsford, NY, pp. 123-130.

4. Morreale de Escobar G, Ruiz de Ona C, Obregon MJ, Escobar del Rey F 1989 Models of fetal iodine deficiency. In: Delong R, Robbins J, Condliffe PG (eds) Iodine and the Brain. Plenum Press, New York, pp. 187-207.

5. Morreale de Escobar G, Obregon MJ, Calvo RM, Escobar del Rey F 1993 The effects of iodine deficiency on thyroid hormone metabolism and brain in fetal rats: The role of the maternal transfer of thyroxine. Am J Clin Nutr 57(Suppl):280S285 S.

6. Morreale de Escobar G, Obregon MJ, Calvo R, Pedraza P, Escobar del Rey F 1997 Iodine deficiency, the hidden scourge: The rat model of human neurological cretinism. In: Hendrich CE (eds) Recent Research Developments in Neuroendocrinology. Thyroid hormone and brain maturation. Research Signpost, Trivandrum, India, pp. 55-70.

7. Studer H, Greer MA 1965 A study of the mechanisms involved in the production of iodine-deficiency goiter. Acta Endocrinol 49:610-628.

8. Heninger RW, Albright EC 1966 Effect of iodine deficiency on iodine-containing compounds of rat tissues. Endocrinology 79:309-315.

9. Inoue K, Taurog A 1968 Sedimentation pattern of soluble protein form thyroids of iodine deficient rats; Acute effects of iodide. Endocrinology 84:816-832.

10. Silva E 1972 Disposal rates of thyroxine and triiodothyronine in iodine-deficient rats. Endocrinology 91:1430-1435.

11. Abrams GM, Larsen PR 1973 Triiodothyronine and thyroxine in the serum and thyroid glands of iodine-deficient rats. J Clin Invest 52:2522-2531.

12. Fukuda H, Yasuda N, Greer MA, Kutas M, Greer SE 1975 Changes in plasma thyroxine, triiodothyronine, and TSH during adaptation to iodine deficiency in the rat. Endocrinology 97:307-314.

13. Heninger RW, Albright EC 1975 Alteration in tissue and serum concentrations of TSH, iodide, $\mathrm{T}_{4}$ and $\mathrm{T}_{3}$ induced by various dietary iodide levels. Proc Soc Expt Biol Med 150:137-141.

14. Riesco G, Taurog A, Larsen PR 1976 Variations in the response of the thyroid gland of the rat to different low-iodine 
diets: Correlation with iodine content of diet. Endocrinology 99:270-280.

15. Riesco G, Taurog A, Larsen PR, Krülich L 1977 Acute and chronic responses to iodine deficiency in rats. Endocrinology 100:303-313.

16. Nakashima T, Taurog A, Krulich L 1981 Serum thyroxine, triiodothyronine, and TSH levels in iodine-deficient and iodine-sufficient rats before and after exposure to cold. Proc Soc Expt Biol Med 167:45-50.

17. Okamura K, Taurog A, Krulich L 1981 Elevation of serum 3,5,3'-triiodothyronine and thyroxine levels in rats fed Remington diets: Opposing effects of nutritional deficiency and iodine deficiency. Endocrinology 108:1247-1256.

18. Okamura K, Taurog A, Krulich L 1981 Hypothyroidism in severely iodine-deficient rats. Endocrinology 109:464-468.

19. Okamura K, Taurog A, Krulich L 1981 Strain differences among rats in response to remington iodine-deficient diets. Endocrinology 109:458-463.

20. Santisteban P, Obregon MJ, Rodriguez-Pena A, Lamas L, Escobar del Rey F, Morreale de Escobar G 1982 Are iodine-deficient rats euthyroid? Endocrinology 110:1780-1789.

21. Obregon MJ, Santisteban P, Rodriguez-Pena A, Pascual A, Cartagena P, Ruiz-Marcos A, Lamas L, Escobar del Rey F, Morreale de Escobar G 1984 Cerebral hypothyroidism in rats with adult-onset iodine deficiency. Endocrinology 115: 614-624.

22. Michalkiewicz M, Huffman L, M. CJ, Hedge GA 1989 Alterations in thyroid blood flow induced by varying lvels of iodine intake in the rat. Endocrinology 125:54-60.

23. Pazos-Moura CC, Moura EG, Dorris MM, Rehnmark S, Melendez L, Silva JE, Taurog A 1991 Effect of iodine deficiency and cold exposure on thyroxine 5 '-deiodinase activity in various rat tissues. Am J Physiol 260(Endocrinol Metab 23): E175-E182.

24. Obregon MJ, Ruiz de Ona C, Calvo R, Escobar del Rey F, Morreale de Escobar G 1991 Outer ring iodothyronine deiodinases and thyroid hormone economy: Responses to iodine deficiency in the rat fetus and neonate. Endocrinology 129:2663-2673.

25. Janssen KP, Van der Heide D, Visser TJ, Kaptein E, Beynen AC 1994 Thyroid function and deiodinase activities in rats with marginal iodine deficiency. Biol Trace Elem Res 40:237-246.

26. Delange D, Ermans AM 1996 Iodine deficiency. In: Braverman LE, Utiger RD (eds) Werner and Ingbar's The Thyroid: 7. Lippincott-Raven, Philadelphia, pp. 296-316.

27. Versloot PM, Schroder-van der Elst JP, van der Heide D, Boogerd L 1997 Effects of marginal iodine deficiency during pregnancy: Iodide uptake by the maternal and fetal thyroid. Am J Physiol 273:E1121-1126.

28. Versloot PM, Schroder-van der Elst JP, van der Heide D, Boogerd L 1998 Effects of marginal iodine deficiency on thyroid hormone production, distribution and transport in nonpregnant and near-term pregnant rats. Eur J Endocrinol 138:713-718.

29. Beckett GJ, Nicol F, Rae PW, Beech S, Guo Y, Arthur JR 1993 Effects of combined iodine and selenium deficiency on thyroid hormone metabolism in rats. Am J Clin Nutr 57:240S-243S.

30. Mitchell JH, Nicol F, Beckett GJ, Arthur JR 1997 Selenium and iodine deficiencies: effects on brain and brown adipose tissue selenoenzyme activity and expression. J Endocrinol 155:255-263.

31. Meinhold H, Campos-Barros A, Walzog B, Kohler R, Muller F, Behne D 1993 Effects of selenium and iodine deficiency on type I, type II and type III iodothyronine deiodinases and circulating thyroid hormones in the rat. Exp Clin Endocrinol 101:87-93.

32. Morreale de Escobar G, Obregon MJ, Calvo RM, Escobar del Rey F 1994 Hormone nurturing of the developing brain: the rat model. In: Stanbury JB (eds) The Damaged Brain of Iodine Deficiency. The Franklin Institute, Philadelphia, pp. 102-122.

33. Greer MA 1968 Qualitative changes in the secretion of thyroid hormones induced by iodine deficiency. Endocrinology 83:1193-1198.

34. Chapman A 1941 The relation of the thyroid and the pituitary glands to iodine metabolism. Endocrinology 29:680681.

35. Halmi NS, Spirtos BN 1955 Analysis of the modifying effect of dietary iodine levels on the thyroidal response of hypophysectomized rats to thyrotropin. Endocrinology 56:157160.

36. Arntzenius AB, Smit LJ, Schipper J, van der Heide D, Meinders AE 1991 Inverse relation between iodine intake and thyroid blood flow: Color Doppler flow imaging in euthyroid humans. J Clin Endocrinol Metab 73:1051-1055.

37. Patel YC, Pharoah OD, Hornabrook RW, Hetzel BS 1973 Serum triiodothyronine, thyroxine and thyroid-stimulating hormone in endemic goiter: A comparison of goitrous and nongoitrous subjects in New Ginea. J Endocrinol Metab 37:783-789.

38. Vagenakis A, Koutras D, Burger A, Malamos B, Ingbar S 1973 Studies of serum triiodothyronine, thyroxine and thyrotropin concentrations in endemic goiter in Greece. J Clin Endocrinol Metab 37:485-488.

39. Missler U, Gutekunst R, Wood WG 1994 Thyroglobulin is a more sensitive indicator of iodine deficiency than thyrotropin: development and evaluation of dry blood spot assays for thyrotropin and thyroglobulin in iodine-deficient geographical areas. Eur J Clin Chem Clin Biochem 32:137-143.

40. Morreale de Escobar G, Obregon MJ, Escobar del Rey F 2004 Role of thyroid hormone during early brain development. Eur J Endocrinol 151,(Suppl 3:U25-U37.

41. Choufoer JC, van Rhijn M, Querido A 1965 Endemic goiter in Western New Guinea. II. Clinical picture, incidence and pathogenesis of endemic cretinism. J Clin Endocrinol Metab 25:385-402.

42. Pharoah POD, Lawton NF, Ellis SM, Williams ES, Ekins RP 1973 The role of triiodothyronine in the maintenance of euthyroidism in endemic goitre. Clin Endocrinol (Oxf) 2:193199.

43. Dumont JE, Corvilain B, Contempré B 1994 Endemic cretinism: The myxoedematous and neurological forms of the disease caused by severe iodine deficiency. In: Stanbury JB (ed) The Damaged Brain of Iodine Deficiency. Cognizant Communication Co, Elmsford, NY, pp. 195-200.

44. Contempre B, Morreale de Escobar G, Denef JF, Dumont JE, Many MC 2004 Thiocyanate induces cell necrosis and and fibrosis in selenium- and iodine-deficient rat thyroids: A potential expedrimental model for myxedematous endemic cretinism in central Africa. Endocrinol 145:99-102.

45. Hetzel BS 1994 Historical development of concepts of brainthyroid relationships. In: Stanbury JB (ed) The Damaged Brain of Iodine Deficiency. Cognizant Communication Co., Elmsford, NY, pp. 1-8.

46. Morreale de Escobar G, Obregon MJ, Escobar del Rey F 2000 Is neuropsychological development related to maternal hypothyroidism or to maternal hypothyroxinemia? J Clin Endocrinol Metab 85:3975-3987. 
47. Delange F, Bordoux P, Ermans AM 1985 Thyroid disfunction in premature infant. Transient disorders on thyroid function and regulation in preterm infants. In: Delange $F$, Fisher DA, Malvaux P, S, Karger AG, Volume 14, Pediatric Thyroidology, Basel, pp. 369-393.

48. Schröder-van der Elst JP, van der Heide D, Morreale de Escobar G, Obregon MJ 1998 Iodothyronine deiodinase activities in fetal rat tissues at several levels of iodine deficiency: A role for the skin in 3,5,3' - triiodothyronine economy? Endocrinology 139:2229-2234.

49. Escobar del Rey F, Ruiz de Ona C, Bernal J, Obregon MJ, Morreale de Escobar G 1989 Generalized deficiency of 3,5,3'triiodo-L-thyronine (T3) in tissues of rats on a low iodine intake, despite normal circulating $\mathrm{T}$ levels. Acta Endocrinologica (Kbhvn) 120:490-498.

50. Guadano-Ferraz A, Obregon MJ, St. Germain DL, Bernal J 1997 The type 2 iodothyronine deiodinase is expressed primarily in glial cells in the neonatal rat brain. Proc Natl Acad Sci USA 94:10391-10396.

51. Tu HM, Kim SW, Salvatore D, Bartha T, Legradi G, Larsen PR, Lechan RM 1997 Regional distribution of type 2 thyroxine deiodinase mRNA in rat hypothalamus and pituitary and its regulation by thyroid hormone. Endocrinology 138:3359-3368.

52. Tu HM, Legradi G, Bartha T, Salvatore D, Lechan RM, Larsen PR 1999 Regional expression of the type 3 iodothyronine deiodinase messenger ribonucleic acid in the rat central nervous system and its regulation by thyroid hormone. Endocrinology 140:784-790.

53. Escamez MJ, Guadano-Ferraz A, Cuadrado A, Bernal J 1999 Type 3 iodothyronine deiodinase is selectively expressed in areas related to sexual differentiation in the newborn rat brain. Endocrinology 140:5443-5446.

54. Guadano-Ferraz A, Escamez MJ, Rausell E, Bernal J 1999 Expression of type 2 iodothyronine deiodinase in hypothyroid rat brain indicates an important role of thyroid hormone in the development of specific primary sensory systems. J Neurosci 19:3430-3439.

55. Campos-Barros A, Amma LL, Faris JS, Shailam R, Kelley MW, Forrest D 2000 Type 2 iodothyronine deiodinase expression in the cochlea before the onset of hearing. Proc Natl Acad Sci USA 97:1287-1292.

56. Peeters R, Fekete C, Goncalves C, Legradi G, Tu HM, Harney JW, Bianco AC, Lechan RM, Larsen PR 2001 Regional physiological adaptation of the central nervous system deiodinases to iodine deficiency. Am J Physiol Endocrinol Metab 281:E54-61.

57. Steinsapir J, Bianco AC, Buettner C, Harney J, Larsen PR 2000 Substrate-induced down-regulation of human type 2 deiodinase (hD2) is mediated through proteosomal degradation and requires interaction with the enzyme's active center. Endocrinology 141:1127-1138.

58. Hetzel BS 1983 Iodine deficiency disorders (IDD) and their eradication. Lancet ii:1126-1129.

59. Bleichrodt N, Escobar del Rey F, Morreale de Escobar G, Garcia I, Rubio C 1989 Iodine deficiency: Implications for mental and psychomotor development in children. In: Delong R, Robbins J, Condliffe PG (eds) Iodine and the Brain. Plenum Press, New York, pp. 268-287.

60. Bleichrodt N, Drenth PJD, Querido A 1980 Effects of iodine deficiency on mental and psychomotor abilities. Am J Phys Anthropol 53:55-67.

61. Vitti P, Aghini-Lombardi F, Chiovato L, Ferretti G, Pinchera A 2003 Neuropsychological assessment in humans living in mild to moderate iodine deficiency. In: Morreale de Escobar
G, deVijlder JJM, Butz S, Hostalek G (eds) The Thyroid and the Brain. Schattauer Verlag, Stuttgart, pp. 57-63.

62. Obregon MJ, Mallol J, Escobar del Rey F, Morreale de Escobar G 1981 Presence of L-thyroxine and 3,5,3'-triiodothyronine in tissues from thyroidectomized rats. Endocrinology 109:908-913.

63. Morreale de Escobar G, Pastor R, Obregon MJ, Escobar del Rey F 1985 Effects of maternal hypothyroidism on the weight and thyroid hormone content of rat embryonic tissues, before and after onset of fetal thyroid function. Endocrinology 117:1890-1900.

64. Perez-Castillo A, Bernal J, Ferreiro B, Pans T 1985 The early ontogenesis of thyroid hormone receptor in the rat fetus. Endocrinology 117:2457-2461.

65. Mellstrom B, Naranjo JR, Santos A, Gonzalez AM, Bernal J 1991 Independent expression of the alpha and beta c-erbA genes in developing rat brain. Mol Endocrinol 5:1339-1350.

66. Bradley DJ, Towle HC, Young WS $1994 \alpha$ - and $\beta$-thyroid hormone receptor (TR) gene expression during auditory neurogenesis: Evidence for TR isoform-specific transcriptional regulation in vivo. Proc Natl Acad Sci 91:439-443.

67. Bradley DJ, Towle HC, Young WS 1992 Spatial and temporal expression of $\alpha$ - and $\beta$-thyroid hormone receptor mRNAs, including the $\beta_{2}$-subtype, in the developing mammalian nervous system. J Neurosci 12:2288-2302.

68. Woods RJ, Sinha AK, Ekins RP 1984 Uptake and metabolism of thyroid hormones by the rat foetus in early pregnancy. Clin Sci (Lond) 67:359-363.

69. Escobar del Rey F, Pastor R, Mallol J, Morreale de Escobar G 1986 Effects of maternal iodine deficiency on the L-thyroxine and 3,5,3'-triiodo-L-thyronine contents of rat embryonic tissues before and after onset of fetal thyroid function. Endocrinology 118:1259-1265.

70. Morreale de Escobar G, Calvo R, Obregon MJ, Escobar del Rey F 1990 Contribution of maternal thyroxine to fetal thyroxine pools in normal rats near term. Endocrinology 126:2765-2767.

71. Vulsma T, Gons MH, de Vijlder JJM 1989 Maternal-fetal transfer of thyroxine in congenital hypothyroidism due to a total organification defect or thyroid agenesis. N Engl J Med 321:13-16.

72. Calvo R, Obregon MJ, Ruiz de Ona C, Escobar del Rey F, Morreale de Escobar G 1990 Congenital hypothyroidism, as studied in rats. Crucial role of maternal thyroxine but not of $3,5,3^{\prime}$-triiodothyronine in the protection of the fetal brain. J Clin Invest 86:889-899.

73. Ruiz de Ona C, Obregon MJ, Escobar del Rey F, Morreale de Escobar G 1988 Developmental changes in rat brain 5'deiodinase and thyroid hormones during the fetal period: The effects of fetal hypothyroidism and maternal thyroid hormones. Pediatr Res 24:588-594.

74. Ruiz de Ona C, Morreale de Escobar G, Calvo RM, Escobar del Rey F, Obregon MJ 1991 Thyroid hormones and 5'-deiodinase in the rat fetus late in gestation: Effects of maternal hypothyroidism. Endocrinology 128:422-432.

75. Schroder-van der Elst JP, van der Heide D, Kastelijn J, Rousset B, Obregon MJ 2001 The expression of the sodium/iodide symporter is up-regulated in the thyroid of fetuses of iodine-deficient rats. Endocrinology 142:3736-3741.

76. van Middlesworth L, Norris CH 1980 Audiogenic seizures and cochlear damage in rats after perinatal antithyroid treatment. Endocrinology 106:1686-1690.

77. van Middlesworth L 1977 Audiogenic seizures in rats after severe prenatal and perinatal iodine depletion. Endocrinology 100:242-245. 
78. Martinez-Galan JR, Pedraza P, Santacana M, Escobar del Ray F, Morreale de Escobar G, Ruiz-Marcos A 1997 Early effects of iodine deficiency on radial glial cells of the hippocampus of the rat fetus. A model of neurological cretinism. J Clin Invest 99:2701-2709.

79. Lavado-Autric R, Auso E, Garcia-Velasco JV, Arufe MC, Escobar del Rey F, Berbel P, Morreale de Escobar G 2003 Early maternal hypothyroxinemia alters histogenesis and cerebral cortex cytoarchitecture of the progeny. J Clin Invest 111: 1073-1082.

80. Auso E, Lavado-Autric R, Cuevas E, Escobar del Rey F, Morreale de Escobar G, Berbel P 2004 A moderate and transient deficiency of maternal thyroid function at the beginning of fetal neocorticogenesis alters neuronal migration. Endocrinology 145:4037-4047.

81. Vermiglio F, Lo Presti VP, Moleti M, Sidoti M, Tortorella G, Scaffidi G, Castagna MG, Violi MA, Crisà A, Artemisia A, Trimarchi F 2004 Attention deficit and hyperactivity disorders (ADHD) in the offspring of mothers exposed to iodine deficiency: A possible novel Iodine Deficiency Disorder in developed countries? J Clin Endocrinol Metab 89:6054-6060.

82. Contempre B, Jauniaux E, Calvo R, Jurkovic D, Campbell S, Morreale de Escobar G 1993 Detection of thyroid hormones in human embryonic cavities during the first trimester of pregnancy. J Clin Endocrinol Metab 77:1719-1722.

83. Calvo RM, Jauniaux E, Gulbis B, Asuncion M, Gervy C, Contempre B, Morreale de Escobar G 2002 Fetal tissues are exposed to biologically relevant free thyroxine concentrations during early phases of development. J Clin Endocrinol Metab 87:1768-1777.

84. Bernal J, Pekonen F 1984 Ontogenesis of the nuclear 3,5,3'triiodothyronine receptor in the human fetal brain. Endocrinology 114:677-679.

85. Ferreiro B, Bernal J, Goodyer CG, Branchard CL 1988 Estimation of nuclear thyroid hormone receptor saturation in human fetal brain and lung during early gestation. J Clin Endocrinol Metab 67:853-856.

86. Iskaros J, Pickard M, Evans I, Sinha A, Hardiman P, Ekins R 2000 Thyroid hormone receptor gene expression in first trimester human fetal brain. J Clin Endocr Metab 85:26202623.
87. Kilby MD, Gittoes N, McCabe C, Verhaeg J, Franklyn JA 2000 Expression of thyroid receptor isoforms in the human fetal central nervous system and the effects of intrauterine growth restriction. Clin Endocrinol (Oxf) 53:469-477.

88. Kester MH, Martinez de Mena R, Obregon MJ, Marinkovic D, Howatson A, Visser TJ, Hume R, Morreale de Escobar G 2004 Iodothyronine levels in the human developing brain: Major regulatory roles of iodothyronine deiodinases in different areas. J Clin Endocrinol Metab 89:3117-3128.

89. Chan S, Kachilele S, McCabe CJ, Tannahill LA, Boelaert K, Gittoes NJ, Visser TJ, Franklyn JA, Kilby MD 2002 Early expression of thyroid hormone deiodinases and receptors in human fetal cerebral cortex. Brain Res Dev Brain Res 138:109-116.

90. Cai L, Brown DD 2004 Expression of type II iodothyronine deiodinase marks the time that a tissue responds to thyroid hormone-induced metamorphosis in Xenopus laevis. Dev Biol 266:87-95.

91. Karmarkar MG, Prabarkaran D, Godbole MM 1993 5'-Monodeiodinase activity in developing human cerebral cortex. Am J Clin Nutr 57:291S-294S.

92. Chan S, Kachilele S, Hobbs E, Bulmer JN, Boelaert K, McCabe CJ, Driver PM, Bradwell AR, Kester M, Visser TJ, Franklyn JA, Kilby MD 2003 Placental iodothyronine deiodinase expression in normal and growth-restricted human pregnancies. J Clin Endocrinol Metab 88:4488-4495.

93. Huang SA, Dorfman DM, Genest DR, Salvatore D, Larsen PR 2003 Type 3 iodothyronine deiodinase is highly expressed in the human uteroplacental unit and in fetal epithelium. J Clin Endocrinol Metab 88:1384-1388.

Address reprint requests to: Maria-Jesus Obregon

Instituto de Investigaciones Biomedicas Alberto Sols Consejo Superior de Investigaciones Cientificas Universidad Autonoma de Madrid Arturo Duperier, 4 28029 Madrid Spain

E-mail: mjobregon@iib.uam.es 